\title{
Микро- и наноструктурирование оптических материалов с помощью фемтосекундного ИК излучения
}

\author{
С.А. Бабин ${ }^{1,2)}$, А.В. Достовалов ${ }^{1,2)}$, А.А. Воль $\phi^{1,2)}$ \\ ${ }^{1}$ Институт автоматики и электрометрии СО РАН, Новосибирск, 630090, Коптюга, 1 \\ ${ }^{2}$ Новосибирский государственный университет, Новосибирск, 630090, Пирогова, 1 \\ тел:+7 (383) 330-6939, факс:+7 (383) 330-8878, эл.nочта: babin@iae.nsk.su
}

DOI 10.34077/RCSP2019-38

Ультракороткая длительность, высокая интенсивность и стабильность фемтосекундных импульсов, генерируемых твердотельными и волоконными лазерами [1] привели к развитию принципиально новых технологий, в частности, технологии микро- и нано-структурирования прозрачных оптических материалов. В докладе будет сделан обзор работ по развитию данного направления на прецизионной фемтосекундной лазерной установке, созданной совместно НГУ и ИАИЭ СО РАН.

Изменение показателя преломления в точке фокуса лазерного импульса (длительностью 230 фс и энергией 100 нДж на длине волны 1030 нм) дает возможность поточечной записи периодических структур в сердцевине одномодового волоконного световода с периодом $\approx 500$ нм [2]. Записанные волоконные брэгговские решётки (ВБР) имеют уникальные параметры: высокую температурную, механическую и радиационную стойкость. При этом ширина спектра отражения длинных (>5см) ВБР составляет <20 пм, а ширина окна пропускания за счет наведенного сдвига фазы в структуре $<1$ пм. Это позволяет создавать на основе таких ВБР прецизионные датчики температуры и деформаций и одночастотные лазеры с распределенной обратной связью с шириной линии генерации $\leq 10$ кГц [3].

Фемтосекундная технология также имеет принципиальные преимущества перед традиционными при формировании структур в многосердцевинных и многомодовых световодах. Высокая точность позиционирования в поперечном сечении световода позволяет формировать решётки в отдельных сердцевинах, причем с разной брэгговской длиной волны [4]. Такие многосердцевинные наборы ВБРдатчиков применены для восстановления формы волокна (как в статическом, так и динамическом режимах), что позволяет создавать 3D-сенсоры для применений в микрохирургии. Это же свойство используется для формирования ВБР в разных областях поперечного сечения многомодовых световодов, что позволяет селектировать отдельные поперечные моды: как фундаментальную $\left(\mathrm{LP}_{01}\right)$, так и высших (например, $\mathrm{LP}_{11}$ ). На этой основе созданы эффективные ВКР-лазеры с прямой диодной накачкой пассивного многомодового градиентного световода, генерирующие в области 950-980 нм [5], где традиционные волоконные лазеры на волокнах, легированных редкоземельными элементами, не работают.

Кроме того, данная технология позволяет изменять показатель преломления в объеме прозрачного материала и формировать волноводные структуры для создания элементов интегральной оптики: разветвители, волноводы, интерферометры Маха-Цендера, модуляторы, поляризационные элементы в различных средах: стекла, кристаллы, полимеры [6]. По сравнению с традиционными методами нанолитографии технология прямой фс лазерной записи обеспечивает более высокую производительность, гибкость при создании различных конфигураций и 3-мерную геометрию записи. Более того, в последнее время развивается направление создания различных оптических элементов непосредственно в кремниевом чипе и записи брэгговских решеток на поверхности $\mathrm{GaN}$ пленок $[7,8]$.

\section{Лumepamypa}

[1] M.E. Fermann, I. Hartl. // Nature Photonics. 2013. V.7, P. 868-874.

[2] A. V. Dostovalov et al. // Opt. Express. 2016. V. 24, P. 16232-16237.

[3] A. Wolf et al. // Opt. Laser Technol. 2018. V.101, P. 202-207.

[4] M.I. Skvortsov et al. // Opt. Lett. 2019. V. 44, P. 295-298.

[5] E.A. Evmenova et al. // Sci. Rep. 2018 V.8, P. 17495.

[6] R. Osellame et al. Femtosecond Laser Micromachining, Springer-V, Berlin, 2012.

[7] O. Tokel et al. // Nat. Photonics. 2017. V. 11, P. 639-645.

[8] A. Halstuch et al. // Opt. Lasers Eng. 2018. V. 109, P. 68-72. 